\section{Follow-up after intravitreal triamcinolone acetonide for exudative age-related macular degeneration}

\author{
Abstract \\ Purpose To report on the follow-up of \\ patients who received an intravitreal \\ triamcinolone acetonide injection (IVTA) as \\ treatment of exudative age-related macular \\ degeneration. \\ Methods The clinical interventional case- \\ series study included 205 patients (222 eyes) \\ with progressive exudative age-related \\ macular degeneration with subfoveal \\ neovascularization who consecutively \\ received an IVTA of about $20 \mathrm{mg}$ as only \\ therapeutic procedure and for whom \\ follow-up was at least 3 months. Mean \\ follow-up was $10.4 \pm 7.1$ months (range, \\ 3-35.7 months). \\ Results Visual acuity improved significantly \\ $(P<0.001)$ from baseline $(0.90 \pm 0.45$ logarithm \\ of the minimum angle of resolution (LogMar)) \\ to a mean minimum of $0.79 \pm 0.42 \mathrm{LogMar}$ \\ during follow-up. In $86(38.7 \%)$ eyes and in 55 \\ $\mathbf{2} 24.8 \%)$ eyes, best visual acuity increased by at \\ least two and three Snellen lines, respectively. \\ Comparing the measurements at specific \\ postinjection examination dates showed that \\ visual acuity measurements taken at 1, 2, and 3 \\ months after injection were not significantly \\ different from the baseline value. \\ Measurements taken at 6, 9, and 12 months \\ after the injection were significantly $(P<0.001)$ \\ lower than the measurements at baseline. \\ Mean loss at 6 months was $1.4 \pm 3.8$ Snellen \\ lines, at 9 months, $2.5 \pm 4.6$ lines, and at 12 \\ months after the injection, $2.6 \pm 4.0$ lines. \\ Intraocular pressure increased significantly \\ $(P<0.001)$ during the first 6 months, and \\ returned to baseline at 9 months after \\ injection.
}

JB Jonas, UH Spandau, BA Kamppeter and B Harder

Conclusions Single injection high-dosage IVTA did not show an apparent benefit at 12 months after injection in patients with neovascular age-related macular degeneration. Eye (2007) 21, 387-394. doi:10.1038/sj.eye.6702222; published online 13 January 2006

Keywords: intravitreal triamcinolone acetonide; intravitreal steroids; age-related macular degeneration; intraocular neovascularization; macular disease

\section{Introduction}

Recent experimental investigations and clinical studies on patients with exudative age-related macular degeneration ${ }^{1-21}$ as well as on patients with other oedematous and neovascular retinal diseases ${ }^{22-26}$ have suggested that the antiangiogenic and antioedematous effect of intravitreal triamcinolone acetonide may be used to treat patients with exudative age-related macular degeneration. In the studies, different dosages varying between about $4 \mathrm{mg}$ to about $20 \mathrm{mg}$ triamcinolone acetonide have been employed. The studies have not been conclusive about the therapeutic value of intravitreal triamcinolone acetonide for treatment of exudative age-related macular degeneration. Some small-scaled case-series investigations using the dosage of about $20 \mathrm{mg}$ triamcinolone acetonide reported a beneficial effect ${ }^{11,15,18,20}$ contradicting a previous randomized clinical trial using a dosage of $4 \mathrm{mg}$ triamcinolone acetonide. ${ }^{14}$ In view of the different results of the previous investigations and different dosages used, it was the purpose of the present
Department of

Ophthalmology, Faculty of Clinical Medicine Mannheim of the University Heidelberg, Mannheim, Germany

Correspondence:

J Jonas, Department of Ophthalmology,

Universitäts-Augenklinik,

Theodor-Kutzer-Ufer 1-3, Mannheim 68167, Germany Tel: +496213832242 or +496213832652;

Fax: + 496213833803 .

E-mail: Jost.Jonas@

augen.ma.uni-heidelberg.de

Received: 31 August 2005 Accepted in revised form: 31 October 2005

Published online:

13 January 2006

Proprietary interest: none 
consecutive case-series study to assess in a longer followup patients who had received an intravitreal high-dosage injection of triamcinolone acetonide.

\section{Patients and methods}

The prospective interventional case-series study included 205 patients (222 eyes) (130 women; 106 right eyes) presenting with progressive decrease of vision due to exudative age-related macular degeneration and who consecutively received an intravitreal injection of triamcinolone acetonide as single and only procedure. A total of 17 patients received the intravitreal cortisone injection in both of their eyes. Mean age was 77.3 \pm 7.4 years (range, 53.9-94.2 years; median, 77.6 years). Refractive error ranged between -7.6 and +5.9 diopters (mean \pm SD: $0.58 \pm 1.89$ diopters; median, 0.25 diopters). Mean intraocular pressure was $15.2 \pm 2.9 \mathrm{mmHg}$ (range, $8-24 \mathrm{mmHg}$; median, $16 \mathrm{mmHg}$ ).

The diagnosis of exudative age-related macular degeneration with subfoveal choroidal neovascularization was substantiated by fluorescein angiography and optical coherence tomography. An occult type of subfoveal neovascularization was present in $87 \%$ of the eyes, a minimally classic type in $6 \%$ of the eyes, and a classic type of subfoveal neovascularization in $7 \%$ of the eyes. For all patients, no other treatment was available since either the subfoveal neovascular membrane was not of the classic type which was the only type for which photodynamic therapy was financially supported by the insurance companies, or because the patients refused undergoing photodynamic therapy. Patients with diabetic maculopathy, retinal vein occlusions, pseudophakic cystoid macular oedema, retinal telangiectasias, or other reasons for macular oedema were excluded from the study. History of glaucoma or of intraocular surgery including cataract surgery or retinal or vitreoretinal surgery were not exclusion criteria. All patients were fully informed about the experimental character of the treatment and consent was obtained from the subjects after the nature of the procedure was explained. The Ethics Committee of the University had approved the study, which followed the tenets of the Declaration of Helsinki.

All patients received an intravitreal injection of about $20 \mathrm{mg}$ triamcinolone acetonide in $0.2 \mathrm{ml}$ Ringer's solution as previously described in detail. ${ }^{27} \mathrm{~A}$ recent study revealed that using the same filtering technique as in the present study, the dosage of triamcinolone acetonide ready for intravitreal injection was about $23.8 \pm 0.6 \mathrm{mg}^{28}$

At baseline of the study, visual acuity and intraocular pressure were determined and fluorescein angiography was performed. After inclusion into the study, the patients were re-examined the first day after the injection, followed by re-examinations in about monthly intervals for the first 3 months after the injection, and in about 3-monthly intervals after that. Mean follow-up was 10.4 \pm 7.1 months (median, 7.5 months; range, 3-35.7 months). Visual acuity was determined in a standardized fashion by an observer performing best-corrected refractometry and using Snellen charts. The visual acuity measurements were given as Snellen lines and in metric units. Additionally, they were converted to the logarithm of the minimum angle of resolution (logMar).

Statistical analyses were performed by using a commercially available statistical software package (SPSS for Windows, version 13.0, SPSS, Chicago IL, USA). For the comparison of frequencies, the $\chi^{2}$ test was applied. The level of significance was 0.05 (two-sided) in all statistical testing.

\section{Results}

Compared with the baseline measurements, visual acuity improved significantly $(P<0.001)$ from $0.90 \pm 0.45$ LogMar $(0.18 \pm 0.14$ Snellen acuity) at baseline to a mean minimum of $0.79 \pm 0.42 \operatorname{LogMar}(0.23 \pm 0.17$ Snellen acuity) during follow-up (Table 1). An increase in best visual acuity during follow-up was found in 129 (58.1\%) eyes. The maximal improvement in visual acuity was on the average $-0.11 \pm 0.30 \operatorname{LogMar}(0.05 \pm 0.14$ Snellen acuity). Expressing visual acuity in Snellen units showed a mean increase in visual acuity by $1.0 \pm 2.9$ Snellen lines (median, 1 Snellen line; range. -10 to +10 lines). In 86 (38.7\%) eyes, best visual acuity increased by at least two Snellen lines. In $55(24.8 \%)$ eyes, best visual acuity increased by at least three Snellen lines. In 31 eyes (14.0\%), best visual acuity dropped by at least two Snellen line during follow-up. In 21 (9.5\%) eyes, best visual acuity decreased by at least three Snellen lines.

If the visual acuity measurements obtained at the single examinations were considered, instead of the best visual acuity measurement obtained at any examination during the whole follow-up, the statistical analysis showed a stabilization of visual acuity during the first 3 months after the injection. The visual acuity measurements taken at 1,2, and 3 months after the injection were not significantly different from the baseline value (Table 1). The measurements taken at 6,9, and 12 months after the injection were significantly $(P<0.001)$ lower than the measurements at baseline (Table 1). Expressed in Snellen lines, mean loss at 6 months was $1.4 \pm 3.8$ lines, at 9 months, $2.5 \pm 4.6$ lines, and at 12 months after the injection, $2.6 \pm 4.0$ lines (Table 1). At 3 months after the injection, $15 \%$ of the eyes showed an increase in visual acuity by at least three lines, and $22 \%$ of the eyes experienced a loss of at least three 
Table 1 Visual acuity at baseline and during follow-up in 222 eyes receiving a single intravitreal injection of about $20 \mathrm{mg}$ triamcinolone acetonide as treatment of exudative age-related macular degeneration

\begin{tabular}{|c|c|c|c|c|}
\hline Visual acuity & $\mathrm{n}$ & $M e a n \pm S D$ & Median & P-value \\
\hline \multicolumn{5}{|l|}{ Baseline } \\
\hline Snellen & 222 & $0.18 \pm 0.14$ & 0.16 & - \\
\hline LogMAR & & $0.90 \pm 0.45$ & 0.80 & - \\
\hline \multicolumn{5}{|l|}{1 month } \\
\hline Snellen & 156 & $0.16 \pm 0.12$ & 0.10 & 0.70 (NS) \\
\hline LogMAR & & $0.91 \pm 0.47$ & 0.82 & 0.73 (NS) \\
\hline Change (Snellen lines) & & $0.00 \pm 0.34$ & 0.00 & \\
\hline Change (LogMAR) & & $0.03 \pm 3.1$ & 0 & \\
\hline Gain three Snellen lines & & $23 / 156(10.3 \%)$ & & \\
\hline Loss three Snellen lines & & $26 / 156(16.7 \%)$ & & \\
\hline \multicolumn{5}{|l|}{2 months } \\
\hline Snellen & 196 & $0.18 \pm 0.15$ & 0.13 & 0.97 (NS) \\
\hline LogMAR & & $0.92 \pm 0.47$ & 0.90 & 0.37 (NS) \\
\hline Change (Snellen lines) & & $-0.20 \pm 3.26$ & 0 & \\
\hline Change (LogMAR) & & $0.03 \pm 0.35$ & 0.00 & \\
\hline Gain three Snellen lines & & $31 / 196(15.8 \%)$ & & \\
\hline Loss three Snellen lines & & $36 / 196(18.4 \%)$ & & \\
\hline \multicolumn{5}{|l|}{3 months } \\
\hline Snellen & 197 & $0.16 \pm 0.17$ & 0.13 & 0.54 (NS) \\
\hline LogMAR & & $0.95 \pm 0.51$ & 0.90 & 0.08 (NS) \\
\hline Change (Snellen lines) & & $-0.39 \pm 3.47$ & 0 & \\
\hline Change (LogMAR) & & $0.05 \pm 0.38$ & 0.00 & \\
\hline Gain three Snellen lines & & $30 / 197(15.2 \%)$ & & \\
\hline Loss three Snellen lines & & $43 / 197(21.8 \%)$ & & \\
\hline \multicolumn{5}{|l|}{6 months } \\
\hline Snellen & 150 & $0.15 \pm 0.15$ & 0.10 & $<0.001$ \\
\hline LogMAR & & $1.03 \pm 0.45$ & 1.00 & $<0.001$ \\
\hline Change (Snellen lines) & & $-1.38 \pm 3.75$ & -1 & \\
\hline Change (LogMAR) & & $0.14 \pm 0.40$ & 0.10 & \\
\hline Gain three Snellen lines & & $17 / 150(11.3 \%)$ & & \\
\hline Loss three Snellen lines & & $51 / 150(34.0 \%)$ & & \\
\hline \multicolumn{5}{|l|}{9 months } \\
\hline Snellen & 69 & $0.13 \pm 0.13$ & 0.08 & $<0.001$ \\
\hline LogMAR & & $1.14 \pm 0.54$ & 1.10 & $<0.001$ \\
\hline Change (Snellen lines) & & $-2.47 \pm 4.57$ & -1 & \\
\hline Change (LogMAR) & & $0.28 \pm 0.57$ & 0.12 & \\
\hline Gain three Snellen lines & & $6 / 69(8.7 \%)$ & & \\
\hline Loss three Snellen lines & & $29 / 69(42.0 \%)$ & & \\
\hline \multicolumn{5}{|l|}{12 months } \\
\hline Snellen & 47 & $0.13 \pm 0.17$ & 0.06 & $<0.001$ \\
\hline LogMAR & & $1.13 \pm 0.48$ & 1.22 & $<0.001$ \\
\hline Change (Snellen lines) & & $-2.62 \pm 4.00$ & -2 & \\
\hline Change (LogMAR) & & $0.26 \pm 0.46$ & 0.26 & \\
\hline Gain three Snellen lines & & $5 / 47(10.6 \%)$ & & \\
\hline Loss three Snellen lines & & $23 / 47(48.9 \%)$ & & \\
\hline
\end{tabular}

$n$ : number of eyes examined; $P$-value: statistical significance of difference to the baseline visual acuity; NS: statistically not significant.

lines. At 6 months after the injection, $11 \%$ of the eyes showed an increase in visual acuity by at least three lines, and $34 \%$ of the eyes experienced a loss of at least three lines. At 12 months after the treatment, the percentage of patients with an increase in visual acuity by at least three lines was reduced to $11 \%$, and the percentage of eyes with a drop in visual acuity by at least three lines was increased to $49 \%$ (Table 1). 
Table 2 Intraocular pressure $(\mathrm{mmHg})$ at baseline and during follow-up in 222 eyes receiving a single intravitreal injection of about $20 \mathrm{mg}$ triamcinolone acetonide as treatment of exudative age-related macular degeneration

\begin{tabular}{lrrc}
\hline Intraocular pressure $(\mathrm{mmHg})$ & Mean \pm SD & Median & P-value \\
\hline Baseline & $15.2 \pm 2.9$ & 16 & - \\
& $17.2 \pm 4.2$ & 17 & $<0.001$ \\
1 month & $2.0 \pm 3.9$ & 2 & \\
Change & $17.4 \pm 4.4$ & 18 & $<0.001$ \\
& $2.2 \pm 3.9$ & 2 & \\
Chonge & $18.2 \pm 6.3$ & 17 & $<0.001$ \\
& $2.7 \pm 6.0$ & 2 & \\
Change & $18.3 \pm 6.2$ & 17 & $<0.001$ \\
& $3.1 \pm 5.8$ & 2 & \\
Chonths & & & \\
& $16.7 \pm 7.2$ & 15 & 0.07 (NS) \\
9 months & $1.7 \pm 7.0$ & 0 & \\
Change & $15.8 \pm 4.2$ & 16 & 0.71 (NS) \\
& $0.5 \pm 4.3$ & 0 & \\
Change &
\end{tabular}

$P$-value: Statistical significance of difference to the baseline visual acuity; NS: statistically not significant.

Intraocular pressure increased significantly $(P<0.001$; Wilcoxon test) from $15.2 \pm 2.9 \mathrm{mmHg}$ (median, $16 \mathrm{mmHg}$; range, $8-24 \mathrm{mmHg}$ ) at baseline of the study to a mean maximum of $21.8 \pm 7.3 \mathrm{mmHg}$ (median, $20 \mathrm{mmHg}$; range, $10-64 \mathrm{mmHg}$ ), and again decreased significantly $(P<0.001)$ towards the end of follow-up to a mean of $16.9 \pm 6.2 \mathrm{mmHg}$ (median, $16 \mathrm{mmHg}$; range, $8-64 \mathrm{mmHg}$ ) (Table 2). At 9 months and at 12 months after the injection, intraocular pressure measurements no longer differed significantly from the baseline values (Table 2). In $87(39.2 \%)$ eyes, at least one intraocular pressure measurement was higher than $21 \mathrm{mmHg}$ at any time during the whole follow-up. In 33 (14.9\%) eyes, at least one intraocular pressure measurement was equal to, or higher than, $30 \mathrm{mmHg}$ at any time during the whole follow-up. In 13 (5.9\%) eyes, intraocular pressure was equal to, or higher than, $35 \mathrm{mmHg}$, and in eight (3.6\%) eyes, at least one intraocular pressure measurement was equal to, or higher than, $40 \mathrm{mmHg}$.

\section{Discussion}

In preceding studies, intravitreal triamcinolone acetonide has been used for treatment of exudative age-related macular degeneration. As an alternative to laser treatment, Penfold, Challa et al started to inject triamcinolone acetonide intravitreally in an effort to treat exudative age-related macular degeneration medically. ${ }^{8}$ In 1998, Challa et $a^{9}$ conducted a nonrandomized clinical pilot study evaluating safety and efficacy of intravitreal injection of $4 \mathrm{mg}$ of triamcinolone after 18 months of follow-up in patients with exudative age-related macular degeneration. Of 20 eyes with initial visual acuity of 0.10 or better, vision was maintained in 11 eyes (55\%), while six eyes (30\%) suffered severe visual loss (six or more lines). Challa et al concluded that $4 \mathrm{mg}$ intravitreal triamcinolone acetonide may be helpful in the treatment of exudative age-related macular degeneration. Danis et $a l^{10}$ examined the effects of $4 \mathrm{mg}$ intravitreal triamcinolone acetonide in a randomized clinical trial on 27 patients with exudative age-related macular degeneration who were compared with a nontreated control group. Visual acuity was significantly $(P<0.005)$ better in the treated group compared with control subjects at 3 and 6 months follow-up. Ranson et al ${ }^{12}$ applied intravitreal triamcinolone as treatment of a recurring subfoveal choroidal neovascularization after laser treatment. Another investigation including 71 eyes with exudative age-related macular degeneration demonstrated a significant increase in visual acuity after an intravitreal injection of about $20 \mathrm{mg}$ of triamcinolone acetonide. ${ }^{15}$ The improvement in visual acuity was significant for the examinations performed 1 month $(P=0.04)$ and 2 months $(P=0.04)$ after the injection. Overall, $48(66.2 \%)$ eyes gained in visual acuity during the follow-up period. In a nonrandomized comparative study, patients with an intravitreal injection of about $20 \mathrm{mg}$ triamcinolone had a significantly better outcome than patients without any treatment for exudative age-related macular degeneration. ${ }^{18}$ In an intereye comparison of patients with bilateral exudative age-related macular degeneration and unilateral intravitreal injection of triamcinolone acetonide, the injected eyes demonstrated a significant gain in visual acuity, while mean visual acuity decreased significantly in the contralateral eyes towards the end of the follow-up. ${ }^{20}$ Patients retreated with an intravitreal injection of $20 \mathrm{mg}$ of triamcinolone acetonide showed a significant reincrease in visual acuity after the second intravitreal injection. ${ }^{17}$ These clinical studies are in agreement with experimental studies on an angiostatic effect of intravitreal cortisone on experimental subretinal neovascularization and other types of intraocular blood vessel proliferation. $4,5,7,29$

The results of the present study show less beneficial results than the previous studies mentioned above. Although visual acuity improved significantly from baseline to a mean maximum during follow-up defined as the best measurement of all postinjection measurements, the comparison between the baseline value and the measurements at specific postinjection 
examination dates showed that during the first 3 months after the injection, visual acuity stabilized, and that at 6 months and later after the injection, visual acuity started to deteriorate significantly (Table 1 ). The present investigation is partially in agreement with a previous pilot study from the same group of authors in which visual acuity was significantly better at three months after the injection than at baseline while at 6 months after the injection, visual acuity significantly deteriorated. ${ }^{15}$ Considering that the patients included in the present study complained about a progressive loss of vision prior to the injection, the results of the present study are also in agreement with another study from the same group of authors in which patients receiving an intravitreal injection of triamcinolone acetonide performed significantly better than patients of a nonrandomized control group; and the results of the present study are in agreement with another investigation in which the injected eyes had a significantly better outcome than the contralateral nontreated eyes in patients with bilateral exudative age-related macular degeneration. ${ }^{18,20}$

Comparing the results obtained at 6 months and at 12 months after the injection in present study with results reported for a combined treatment of intravitreal triamcinolone acetonide and verteporfin photodynamic therapy suggests that the combined treatment may be superior to the intravitreal triamcinolone acetonide monotherapy. ${ }^{16,30-35}$ Spaide et $a l^{16}$ were the first to report on the combination of intravitreal triamcinolone acetonide with photodynamic therapy as treatment of exudative age-related macular degeneration. Their study included 26 eyes with exudative age-related macular degeneration with choroidal neovascularization. A total of 13 eyes had already received a photodynamic therapy and experienced visual loss after the treatment. A total of 13 additional eyes had not been treated with photodynamic therapy prior to inclusion into the study. In the study, all patients were treated with photodynamic therapy immediately followed by an intravitreal injection of $4 \mathrm{mg}$ of triamcinolone acetonide. Of the 13 patients, who received the combination treatment as first procedure, mean visual acuity change at 3 months follow-up was an improvement of 1.9 lines, and four eyes $(30.8 \%)$ had an improvement of at least three lines. Two patients $(15.4 \%)$ required retreatment at 3 months. At the 6-month follow-up, the mean visual acuity change from baseline was an improvement of 2.4 lines, four patients (33\%) had an improvement of at least three lines and one patient required retreatment. At both time points, visual acuity was significantly greater than at baseline $(P=0.023$ and $P=0.007)$. Among the 13 patients who had already undergone photodynamic treatment prior to inclusion in the study, mean change in visual acuity from baseline at the 3-month follow-up was 0.31 lines and one patient $(7.7 \%)$ had an improvement of at least three lines. At 6-month follow-up, available for 11 patients, mean change from baseline visual acuity was 0.1 lines and one patient $(9.1 \%)$ experienced an improvement of three or more lines. None of the patients required retreatment at 3 or 6 months. At the 3- and 6-month time points the visual acuity was not significantly different than the baseline acuity. In a second study, Spaide et $a l^{30}$ confirmed the results of the previous investigation. The newly treated patients $(n=13)$ had a mean improvement of 2.5 lines 12 months after the combination treatment, while patients in the prior photodynamic therapy group $(n=13)$ had a mean improvement of 0.4 lines. In a similar study by Rechtman et al, ${ }^{32}$ intravitreal triamcinolone acetonide was used as an adjunctive treatment to photodynamic therapy with verteporfin for new subfoveal choroidal neovascularization in age-related macular degeneration. In all, 14 patients who had received intravitreal triamcinolone acetonide within 6 weeks of their first photodynamic therapy and who had a follow-up of 1 year or longer were included into the study. In all, 11 patients received one initial combined treatment and three received an additional combined treatment after 6 months. Overall, $7 \%$ of the patients gained by 30 or more letters, $50 \%$ of the patients maintained stable vision, $14 \%$ patients lost 15-29 letters, and 29\% of the patients lost 30 or more letters. The mean number of photodynamic therapies during the first year was 2.57. Arevalo et $a l^{33}$ performed an indocyanine green-mediated photothrombosis with intravitreal triamcinolone acetonide for subfoveal choroidal neovascularization in age-related macular degeneration and concluded that combined indocyanine green-mediated photothrombosis with intravitreal TA may provide stability or improvement in visual acuity and fundus findings in choroidal neovascularization.

Although randomized trials comparing an intravitreal triamcinolone acetonide monotherapy with a combination of intravitreal triamcinolone acetonide and photodynamic therapy for the treatment of exudative age-related macular degeneration have not been published yet, and although photodynamic therapy may lead to a collateral tissue damage in the macula in contrast to intravitreal triamcinolone acetonide, ${ }^{36}$ the present study in combination with results published in the literature may suggest that the combined treatment consisting of verteporfin photodynamic therapy and intravitreal triamcinolone acetonide may be superior to the intravitreal triamcinolone acetonide monotherapy.

It remains unclear whether the results of the high-dosage intravitreal triamcinolone acetonide monotherapy compare well with studies using other treatment modalities such as verteporfin photodynamic 
therapy as single treatment or using other angiostatic agents such as pegaptanib, anecortave acetate and ranibizumab. ${ }^{37-40}$ In the present study, a drop in visual acuity of at least three lines occurred in $34 \%$ of the eyes at 6 months after the injection, while $11 \%$ of the eyes showed an increase in visual acuity by three or more lines at the same time. At 12 months after the injection, $49 \%$ of the eyes had experienced a decrease in visual acuity by at least three lines, and $11 \%$ of the eyes showed an increase in visual acuity by three or more lines (Table 1). An indirect comparison between the results of the present study and the results of the investigations using other therapies may not be possible due to different inclusion criteria. Comparing the data of the present investigations with control groups from other studies, one may infer, however, that the visual outcome of the patients included in the present study may not be worse than those of the patients of the control groups. It does, however, not answer the question of the riskbenefit ratio of the intravitreal triamcinolone acetonide treatment.

The main side effect of intravitreal triamcinolone acetonide observed in the present study was an elevation of intraocular pressure. Similar to previous reports, about $40 \%$ of the eyes developed a triamcinolone acetonide induced ocular hypertension with at least one intraocular pressure measurement higher than $21 \mathrm{mmHg}$ at any examination during the whole follow-up. ${ }^{41,42} \mathrm{~A}$ measurement higher than $30 \mathrm{mmHg}$ was obtained about $15 \%$ of the eyes, and about $4 \%$ of eyes showed an intraocular pressure higher than $40 \mathrm{mmHg}$. The increased intraocular pressure returned to the normal range within 9 months after the injection. This finding is in agreement with previous studies in which the duration of the effect and side effect (intraocular pressure elevation) of the high-dosage intravitreal triamcinolone acetonide (about $20 \mathrm{mg}$ ) was about 6-8 months. ${ }^{43}$ With the solvent agent mostly removed, other side effects or complications of intravitreal triamcinolone acetonide, such as noninfectious or infectious endophthalmitis, were not observed in the present study. ${ }^{4-46}$

There are limitations of the present study one of which is the design as a nonrandomized case-series investigation. Another limitation may be that, although intravitreal triamcinolone will have increased cataract, cataract surgery was not performed in combination with, or after the intravitreal injection. The vision-reducing effect of progressive cataract, however, may have hidden parts of a vision improving effect of triamcinolone. An additional limitation of the study is the method to measure visual acuity. Instead of using visual acuity charts which were also taken for the early treatment of diabetic retinopathy study (ETDRS), visual acuity was determined using Snellen charts in a standardized fashion by an observer performing best-corrected refractometry.

In conclusion, the data of the present study may suggest that the intravitreal injection of about $20 \mathrm{mg}$ of triamcinolone acetonide as treatment of progressive exudative age-related macular degeneration may lead to a temporary stabilization of visual acuity for about 3 months in patients with progressive exudative agerelated macular degeneration. At 6 months and at 12 months after the single high-dosage injection of triamcinolone, however, visual acuity was significantly deteriorated as compared with the baseline value suggesting that the treatment is not effective at 12 months after a single injection. In view of the significant decrease in visual acuity at 6 months and at 12 months after the injection, and considering the results reported for a combination of intravitreal triamcinolone acetonide with verteporfin photodynamic therapy, one may infer to combine intravitreal triamcinolone acetonide with verteporfin photodynamic therapy. ${ }^{47}$

\section{References}

1 Machemer R, Sugita G, Tano Y. Treatment of intraocular proliferations with intravitreal steroids. Trans Am Ophthalmol Soc 1979; 77: 171-180.

2 Tano Y, Chandler D, Machemer R. Treatment of intraocular proliferation with intravitreal injection of tramcinolone acetonide. Am J Ophthalmol 1980; 90: 810-816.

3 Tano Y, Sugita G, Abrams G, Machemer R. Inhibition of intraocular proliferation with intravitreal corticosteroid. Am J Ophthalmol 1980; 89: 131-136.

4 Ishibashi T, Miki K, Sorgente N, Patterson R, Ryan SJ. Effects of intravitreal administration of steroids on experimental subretinal neovascularization in the subhuman primate. Arch Ophthalmol 1985; 103: 708-711.

5 Antoszyk AN, Gottlieb JL, Machemer R, Hatchell DL. The effects of intravitreal triamcinolone acetonide on experimental pre-retinal neovascularization. Graefes Arch Clin Exp Ophthalmol 1993; 231: 34-40.

6 Machemer R. Five cases in which a depot steroid (hydrocortisone acetate and methylprednisolone acetate) was injected into the eye. Retina 1996; 16: 166-167.

7 Danis RP, Bingaman DP, Yang Y, Ladd B. Inhibition of preretinal and optic nerve head neovascularization in pigs by intravitreal triamcinolone acetonide. Ophthalmology 1996; 103: 2099-2104.

8 Penfold PL, Gyory JF, Hunyor AB, Billson FA. Exudative macular degeneration and intravitreal triamcinolone. A pilot study. Aust NZ J Ophthalmol 1995; 23: 293-298.

9 Challa JK, Gillies MC, Penfold PL, Gyory JF, Hunyor AB, Billson FA. Exudative macular degeneration and intravitreal triamcinolone: 18 month follow up. Aust NZ J Ophthalmol 1998; 26: 277-281.

10 Danis RP, Ciulla TA, Pratt LM, Anliker W. Intravitreal triamcinolone acetonide in exudative age-related macular degeneration. Retina 2000; 20: 244-250.

11 Jonas JB, Kreissig I, Degenring RF. Repeated intravitreal injections of triamcinolone acetonide as treatment of 
progressive exudative age-related macular degeneration. Graef Arch Clin Exp Ophthalmol 2002; 240: 873-874.

12 Ranson NT, Danis RP, Ciulla TA, Pratt L. Intravitreal triamcinolone in subfoveal recurrence of choroidal neovascularisation after laser treatment in macular degeneration. Br J Ophthalmol 2002; 86: 527-529.

13 Penfold PL. Intravitreal triamcinolone in recurrence of choroidal neovascularisation. Br J Ophthalmol 2002; 86: 600-601.

14 Gillies MC, Simpson JM, Luo W, Penfold P, Hunyor HB, Chua $\mathrm{W}$ et al. A randomized clinical trial of a single dose of intravitreal triamcinolone acetonide for neovascular age-related macular degeneration: one-year results. Arch Ophthalmol 2003; 121: 667-873.

15 Jonas JB, Kreissig I, Hugger P, Sauder G, Panda-Jonas S, Degenring $R$. Intravitreal triamcinolone acetonide for exudative age-related macular degeneration. $\mathrm{Br} \mathrm{J}$ Ophthalmol 2003; 87: 462-468.

16 Spaide RF, Sorenson J, Maranan L. Combined photodynamic therapy with verteporfin and intravitreal triamcinolone acetonide for choroidal neovascularization Ophthalmology 2003; 110: 1517-1525.

17 Jonas JB, Akkoyun I, Budde WM, Kreissig I, Degenring RF. Intravitreal re-injection of triamcinolone for exudative age-related macular degeneration. Arch Ophthalmol 2004; 122: 218-222.

18 Jonas JB, Degenring RF, Kreissig I, Friedemann T, Akkoyun I. Exudative age-related macular degeneration treated by intravitreal triamcinolone acetonide. A prospective comparative non-randomized study. Eye 2005; 19: 163-170.

19 Jonas JB, Kreissig I, Degenring RF. Factors influencing visual acuity after intravitreal triamcinolone acetonide as treatment of exudative age-related macular degeneration. Br J Ophthalmol 2004; 88: 1557-1562.

20 Jonas JB, Spandau UH, Harder B, Vossmerbaeumer U, Kamppeter BA. Inter-eye difference in exudative agerelated macular degeneration with minimally classic or occult subfoveal neovascularisation after unilateral intravitreal injection of triamcinolone acetonide. $A m \mathrm{~J}$ Ophthalmol 2005; 139: 1073-1079.

21 Jonas JB, Kreissig I, Degenring RF. Intravitreal triamcinolone acetonide for treatment of intraocular proliferative, exudative and angiogenic diseases. Prog Ret Eye Res 2005; 5: 587-611.

22 Jonas JB, Hayler JK, Söfker A, Panda-Jonas S. Intravitreal injection of crystalline cortisone as adjunctive treatment of proliferative diabetic retinopathy. Am J Ophthalmol 2001; 131: $468-471$.

23 Jonas JB, Söfker A. Intraocular injection of crystalline cortisone as adjunctive treatment of diabetic macular oedema. Am J Ophthalmol 2001; 132: 425-427.

24 Martidis A, Duker JS, Greenberg PB, Rogers AH, Puliafito $\mathrm{CA}$, Reichel $\mathrm{E}$ et al. Intravitreal triamcinolone for refractory diabetic macular oedema. Ophthalmology 2002; 109: 920-927.

25 Jonas JB, Hayler JK, Söfker A, Panda-Jonas S. Regression of neovascular iris vessels by intravitreal injection of crystalline cortisone. J Glaucoma 2001; 10: 284-287.

26 Greenberg PB, Martidis A, Rogers AH, Duker JS, Reichel E. Intravitreal triamcinolone acetonide for macular oedema due to central retinal vein occlusion. Br J Ophthalmol 2002; 86: $247-248$.

27 Jonas JB, Kreissig I, Degenring RF. Endophthalmitis after intravitreal injection of triamcinolone acetonide. Arch Ophthalmol 2003; 121: 1663-1664.
28 Spandau UHM, Derse M, Schmitz-Valckenberg P, Papoulis C, Sagstetter BU, Stiefvater KH et al. Measurement of triamcinolone acetonide concentration after filtering of solvent agent. Am J Ophthalmol 2005; 139: 712-713.

29 Spandau U, Sauder G, Schubert U, Hammes HP, Jonas JB. Effect of triamcinolone acetonide on proliferation of retinal endothelial cells in vitro and in vivo. Br J Ophthalmol 2005; 89: 745-747.

30 Spaide RF, Sorenson J, Maranan L. Photodynamic therapy with verteporfin combined with intravitreal injection of triamcinolone acetonide for choroidal neovascularization. Ophthalmology 2005; 112: 301-304.

31 Smithen LM, Spaide RF. Photodynamic therapy and intravitreal triamcinolone for a subretinal neovascularization in bilateral idiopathic juxtafoveal telangiectasis. Am J Ophthalmol 2004; 138: 884-885.

32 Rechtman E, Danis RP, Pratt LM, Harris A. Intravitreal triamcinolone with photodynamic therapy for subfoveal choroidal neovascularization in age related macular degeneration. Br J Ophthalmol 2004; 88: 344-347.

33 Arevalo JF, Garcia RA, Mendoza AJ. Indocyanine greenmediated photothrombosis with intravitreal triamcinolone acetonide for subfoveal choroidal neovascularization in age-related macular degeneration. Graefes Arch Clin Exp Ophthalmol 2005 May 20; [E-pub ahead of print].

34 Augustin AJ, Schmidt-Erfuhrt U. Verteporfin therapy combined with intravitreal triamcinolone in all types of choroidal neovascularisation due to age-related macular degeneration. Ophthlmology 2005, in press.

35 Augustin AJ, Schmidt-Erfuhrt U. Verteporfin and intravitreal triamcinolone acetonide combination therapy for occult choroidal neovascularisation in age-related macular degeneration. Am J Ophthalmol 2005, in press.

36 Schlotzer-Schrehardt U, Viestenz A, Naumann GO, Laqua $\mathrm{H}$, Michels S, Schmidt-Erfuhrt U. Dose-related structural effects of photodynamic therapy on choroidal and retinal structures of human eyes. Graefes Arch Clin Exp Ophthalmol 2002; 240: 748-757.

37 Gragoudas ES, Adamis AP, Cunningham Jr ET, Feinsold M, Guyer DR, VEGF Inhibition Study in Ocular Neovascularization Clinical Trial Group. Pegaptanib for neovascular age-related macular degeneration. $N$ Engl J Med 2004; 351: 2805-2816.

38 D'Amico DJ, Goldberg MF, Hudson H, Jerdan JA, Krueger DS, Luna SP et al. Anecortave acetate as monotherapy for treatment of subfoveal neovascularization in age-related macular degeneration: twelve-month clinical outcomes. Ophthalmology 2003; 110: 2372-2383.

39 Husain D, Kim I, Gauthier D, Luna AM, Tsilimbaris MK, Ezra E et al. Safety and efficacy of intravitreal injection of ranibizumab in combination with verteporfin PDT on experimental choroidal neovascularization in the monkey. Arch Ophthalmol 2005; 123: 509-516.

40 Verteporfin in Photodynamic Therapy (VIP) Study Group. Verteporfin therapy of subfoveal choroidal neovascularization in age-related macular degeneration: two year results of a randomized clinical trial including lesions with occultwith no classic choroidal neovascularization-Verteporfin in Photodynamic therapy report 2. Am J Ophthalmol 2001; 131: 541-560.

41 Wingate RJ, Beaumont PE. Intravitreal triamcinolone and elevated intraocular pressure. Aust NZ J Ophthalmol 1999; 27: 431-432. 
42 Jonas JB, Degenring RF, Kreissig I, Akkoyun I, Kamppeter BA. Intraocular pressure elevation after intravitreal triamcinolone acetonide injection. Ophthalmology 2005; 112: 593-598.

43 Jonas JB, Degenring R, Kamppeter B, Kreissig I, Akkoyun I Duration of the effect of intravitreal triamcinolone acetonide as treatment of diffuse diabetic macular oedema. Am J Ophthalmol 2004; 138: 158-160.

44 Sutter FK, Gillies MC. Pseudo-endophthalmitis after intravitreal injection of triamcinolone. Br J Ophthalmol 2003; 87: 972-974.
45 Roth DB, Chieh J, Spirn MJ, Green SN, Yarian DL, Chaudhry NA. Noninfectious endophthalmitis associated with intravitreal triamcinolone injection. Arch Ophthalmol 2003; 121: $1279-1282$

46 Gillies MC, Simpson JM, Billson FA, Luo W, Penfold P, Chua $\mathrm{W}$ et al. Safety of an intravitreal injection of triamcinolone: results from a randomized clinical trial. Arch Ophthalmol 2004; 122: 336-340.

47 Kaiser PK. Verteprofin therapy in combination with triamcinolone: published studies investigating a potential synergistic effect. Curr Med Res Opinion 2005; 5: 705-706. 